\title{
FRENCH EXISTENTIALISM AND AMERICAN POPULAR CULTURE, 1945-1948
}

\author{
GEORGE COTKIN
}

The translation in 1947 of Jean-Paul Sartre's lecture, "Existentialism is a 1 Humanism" (1945), insured that the term existentialism would enter into the vocabulary of American thought and culture. Existentialism is notoriously difficult to define, especially since it claims a varied philosophical background, drawing from René Descartes, Søren Aabye Kierkegaard, Friedrich Wilhelm Nietzsche, and Martin Heidegger. Moreover, as Gabriel Marcel and others announced, an existentialist could believe in God as mightily as a Sartrean embraced atheism. Sarte's existentialism, in its boldest outlines, came to rest on the assertion that man is free, and that in having the freedom to choose, man encounters anxiety and despair. While existentialism in Sartre's hands often dwelled on the absurd and problematic nature of human existence, the essential conclusion that the existential perspective drew was that our existence is of our own making; we are responsible for our fates. This "dreadful freedom" was at once exhilarating and frightening.

In his introduction to Sartre's lecture on existentialism, translator Bernard Frechtman remarked that the American vogue for Sartre's "philosophy, which had begun in 1945 was ... one of those curious phenomena which might, if properly examined, illuminate some peculiarities of culture in America." Alas, Frechtman failed to develop this insight, although he did suggest that the popular press in America had focused too much on Sartre's personality and too little on his ideas. ${ }^{2}$

Examination of the initial dissemination of French existentialism in American popular culture reveals a number of intertwined themes. First, much of the American fascination with French existentialism was rooted in what French sociologist Pierre Bourdieu calls "cultural capital," the power of certain cultural representations to command prestige and respect. ${ }^{3}$ Thus, from the start, fashion and idea

George Cotkin is a professor of history at California Polytechnic State University.

\footnotetext{
${ }^{1}$ Jean-Paul Sartre, Existentialism (New York, 1947), 18-28, passim; Marjorie Grene, Dreadful Freedom: A Critique of Existentialism (Chicago, 1948).

${ }^{2}$ Bernard Frechtman, introduction to Existentialism, by Jean-Paul Sartre (New York, 1947), 1.

${ }^{3}$ Pierre Bourdieu, Distinction: A Social Critique of the Judgment of Taste, trans. Richard Nice (Cambridge, 1984).
} 


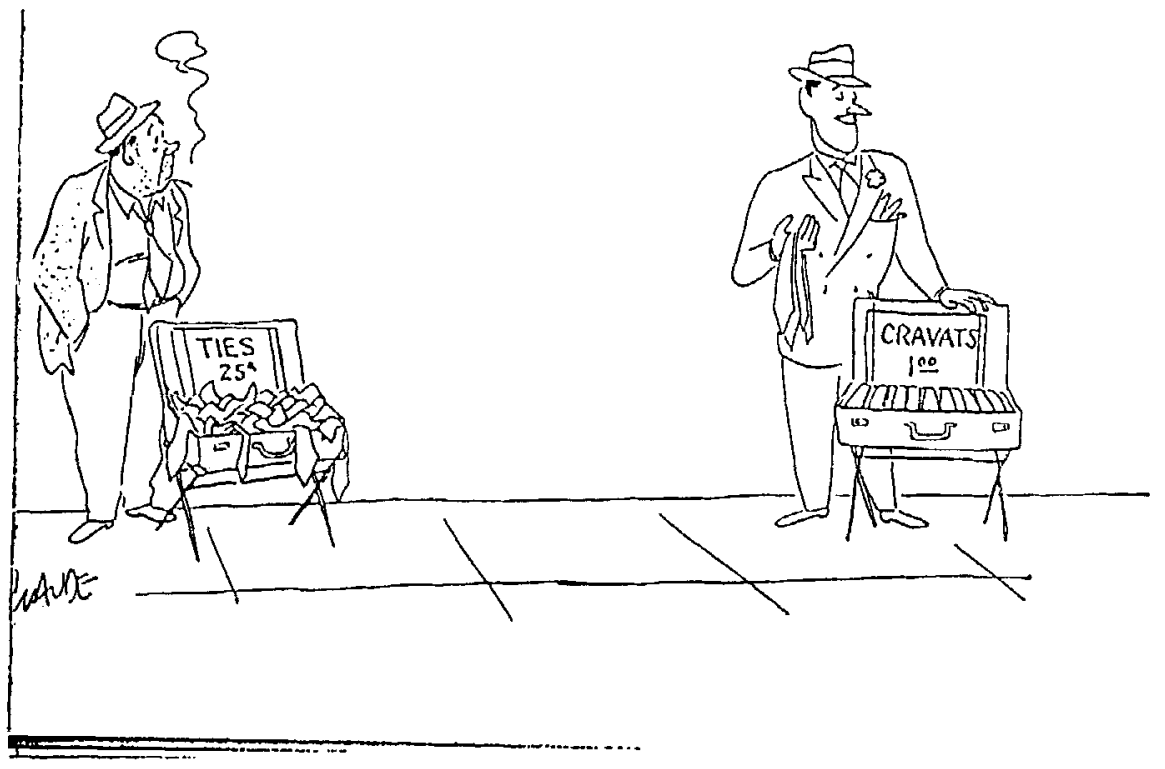

Drawing by Claude; $C$ 1948, The New Yorker Magazine, Inc.

coexisted to define the dissemination of French existentialism in America. Second, American coverage of French existentialists such as Sartre, Simone de Beauvoir, and Albert Camus exemplified what historian Daniel Boorstin calls the predominance of the celebrity in modern American culture. The popular reception of existentialism in America was as much about the image of the intellectual as the content of existentialist ideas. Third, Sartre and other existentialists were portrayed in American popular culture as exemplary of "an erratic left-bank bohemianism," 4 an image that fit poorly with postwar celebrations of the American intellectual as a sober minded, optimistic, and respectable citizen. By popularizing French existentialists as celebrities and associating their pessimistic philosophy with the trauma France had experienced in World War II, the popular press undermined their reception by the American intellectual community. Many considered existentialism a passing vogue, not centrally applicable to the life of the mind in America. Thus, the cultural politics for the dissemination of existentialism in America became complex, marked by tensions in control of the cultural capital associated with French

${ }^{4}$ Daniel Boorstin, The Image: A Guide to Pseudo-Events in America (1961, New York, 1992), 45-76; Frechtman, introduction to Existentialism, 1. 


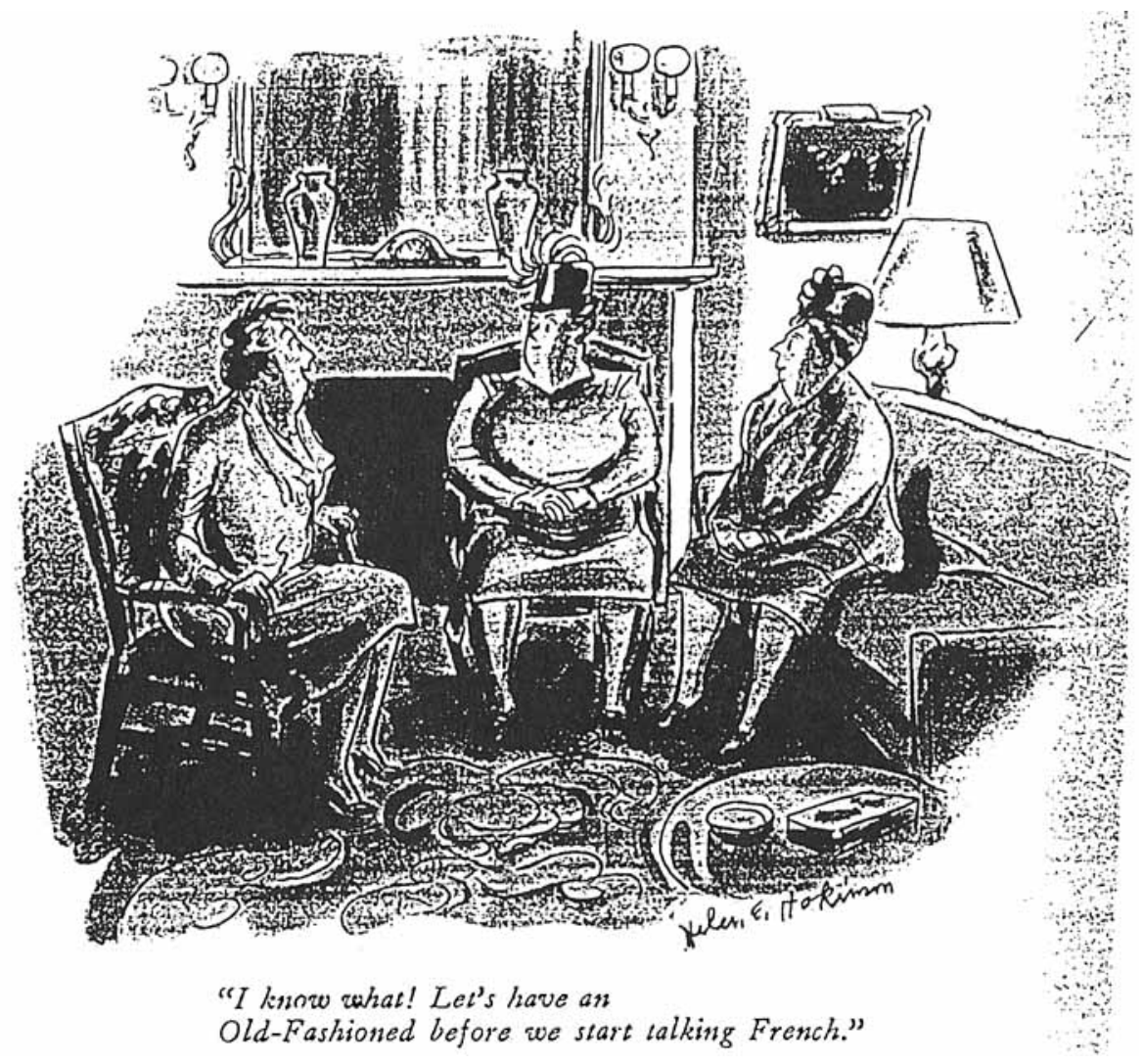

Drawing by Helen E. Hokinson; 0 1947, The New Yorker Magazine, Inc.

culture and the image of the intellectual. It was nearly 20 years before existentialism was accepted as a viable philosophy relevant to the modern American intellectual community.

Americans in the 1940s highly valued French ideas, art, and fashion, less for any essential quality than for the prestige that came with their French label. These perceptions were satirized in two cartoons that ran in the late 1940s in the New Yorker, which apotheosized a certain popular, middlebrow style in America. In one cartoon, a rather disheveled street vendor selling ties at 25 cents each looks askance at his welldressed competitor who is able to sell the same items, elegantly called cravats, at one dollar apiece (Figure 1). Another cartoon shows a doughty group of women, one of whom exclaims: "I know what! Let's have an Old-Fashioned before we start talking 
French" (Figure 2). The allure of France, of things French in American culture, must not be underestimated as a continuing theme in accounts of the popularity of existentialism and of existential thinkers, and existential thinkers consciously played on this fascination.

Before the Second World War in Europe had ended, before the atomic bomb had forever scarred the physical and mental landscape of modern men and women, the existential figure and ideas of Jean-Paul Sartre had alighted on American shores. Sartre was determined to become an influential figure in both Europe and the United States. In "Paris Alive," translated by Lincoln Kirstein, which appeared in the December 1944 issue of Atlantic Monthly, Sartre introduced himself to Americans. In a note to the essay, the editors of the magazine characterized Sartre, incorrectly, as "one of the military leaders" of the French resistance during the war. Although Sartre did not refer to himself as a leader, he universalized his discussion of the psychological impact of German occupation upon the French by pronouncing: "Never were we freer than under the German occupation." With this strange, apparently contradictory observation about the nature of freedom, Sartre began to communicate existentialist ideas--without naming them formally-to his American audience. In the essay, Sartre also touched upon themes that would later become associated with the essentials of an existentialist perspective: authenticity, choice, the presence of death, loneliness, responsibility, and the notion that "in his freedom in choosing himself, he [man] chose the freedom of all."

Major introductions to existentialism appeared in Life, the New York Times Magazine, Time, Newsweek, and fashion magazines such as Vogue and Harper's Bazaar between 1945 and 1948. The dissemination of existentialist ideas and personalities in the popular press was more than a story being narrated upon the inert intellectual bodies of Sartre, Beauvoir, Camus, and existentialism. As Anna Boschetti has noted, Sartre and his followers had carefully orchestrated their reception in order to capture the French intellectual field, thus assuring, albeit briefly, that existentialism would dominate. Sartre and Beauvoir attempted to influence the reception of their philosophical perspective on the American intellectual field as well. ${ }^{6}$

In their early articles, as well as their personal interventions in American intellectual life, Sartre and Beauvoir accepted a model of the philosopher as personality or celebrity. Further, they chose to publicize themselves in American popular journals, particularly fashion magazines. Vogue, a leading fashion magazine now traf-

${ }^{5} J$ can-Paul Sartre, "Paris Alive: The Republic of Silence," Atlantic Monthly, December 1944, 39-40.

${ }^{6}$ Anna Boschetti, The Intellectual Enterprise: Sartre and Les Temps Modernes, trans. Richard C. McCleary (Evanston, 1988). 
ficking in fashionable ideas and philosophers, published Sartre's piece, "New Writing in France," which again described the lessons that the Resistance experience had communicated to the French. In this essay, he emphasized how young writers, tortured both literally and figuratively in the war, were bursting forth with a new, hardier French fiction. Camus was showcased as a writer to be reckoned with, and the French existentialist emphasis on a "profound pessimism" arising out of the confrontation with "the reality of Evil" became a trademark for nearly all subsequent discussions of French existentialism. ${ }^{7}$ Still, the figure of Sartre loomed as large and compelling as his ideas; Vogue described him as looking "like the men on the barricades in pictures of the Paris Insurrection. Just forty, he is small, intent ... [with] his worn trench coat, his pipe, his heavy-rimmed glasses ... indeed, a man of the Resistance."8

As Sartre's fame and the popularity of existentialism rocketed in 1946, fashion magazines turned again to Camus, this time focusing even more on the visage than on the ideas. Vogue's "Portraits of Paris" featured a haunting portrait of Camus taken by Cecil Beaton. Camus, in a dark-lit, noir photograph, was described as an editor for the Resistance paper Combat and as a popular playwright. His The Stranger "stresses the absurdity of man's predicament," but in "his philosophical lectures Camus is far from despair, saying in effect that in the present crisis of man fear is the great enemy." A less impressive portrait of Sartre, standing in front of a modern painting and surrounded by open, folio-sized art books, was also included in the piece. This time Sartre, "a former Resistance writer," was explicitly named as the "leading exponent of the controversial French philosophy of Existentialism," though there was little exemplification of the ideas themselves. ${ }^{9}$

As the ideas of existentialism began to appear in intellectual journals in 1946 and 1947, the image of Sartre as the quintessential French intellectual continued to grace fashion magazines. In an important piece, Sartre was profiled in Harper's Bazaar by his compatriot and paramour, Simone de Beauvoir, who presented his ideas and personality side by side. The piece was subtitled "Strictly Personal," as if Sartre's personality might be extricated from his philosophy. The essay helped to feed the developing American frenzy to see Sartre as a representative type, the existentialist as intellectual celebrity. This was clearly a conscious decision on the part

\footnotetext{
${ }^{7}$ Jean-Paul Sartre, "The New Writing in France: The Resistance 'Taught that literature is no fancy activity independent of politics," Vogue, July 1945, 84.

${ }^{8}$ Ibid., 85.

9“Portraits of Paris," Vogue, June 1946, 157, 162.
} 
of both Sartre and Beauvoir, since they were always careful to cultivate their image as a means of gaining greater influence.

Beauvoir quickly dealt with the essentials of existentialist philosophy that Sartre had detailed in "his big philosophical work, L'Etre et le Néant" (did the untranslated title have more allure, more authority?), and in his novels and plays. In contrast to most people who did not exercise their liberty, who "put their consciousness to sleep," Sartre "passionately refuses to exist in the mood of things, and tries to affirm himself as consciousness and pure liberty." But this apostle of consciousness and liberty, Beauvoir continued, "hates the country... [H]e feels at home only in cities, in the heart of an artificial universe filled with man-made objects." In shotgun fashion, Beauvoir revealed the essence that was Sartre, his likes and dislikes, his personality, concluding: Sartre "feels no qualms about being happy, for he is convinced that other men can discover, more or less readily in the consciousness of their own liberty, a joy as solid as his own." ${ }^{10}$ Beauvoir's wide-ranging and influential essay was quoted in a Time magazine article of January 1946, which began by announcing that " $[t]$ he literary lion of Paris bounced into Manhattan last week." The writer proceeded to tell American readers about Sartre's eating and living habits, while also emphasizing the faddish nature of existentialism. "

The connection between fashion and existentialism, the notion that existentialism was a vogue or a fad, was thus quickly established, helped in no small manner by its early coverage in magazines such as Vogue and Harper's Bazaar, and the attention paid to it in middlebrow publications such as Time, Newsweek, and the New Yorker. Janet Flanner, writing as Gênet, was one of the first to describe existentialism for an American audience in her "Paris Journal" column for the New Yorker. In December 1945, she found that "Sartre is automatically fashionable now among those who once found Surrealism automatically fashionable." 12 Time called Sartre's philosophy "another faddist version of Materialism"13 and a few months later, in a review of Camus's The Stranger, dismissed existentialism as "the latest highbrow buzz-fuzz." ${ }^{14}$ Writing in the Nation around this time, art critic Clement Greenberg

\footnotetext{
${ }^{10}$ Simone de Beauvoir, "Strictly Personal," trans. Malcolm Cowley, Harper's Bazaar, January 1946, 113,160 .

${ }^{11}$ Time, 28 January $1946,28-29$.

${ }^{12}$ Flanner, "Paris Journal" for 5 December 1945, in Janet Flanner, Paris Journal, 1944-1965, ed. William Shawn (New York, 1965), 49.

13"Existentialism," Time, 28 January 1946, 29.

14"Man in a Vacuum," Time, 20 May 1946, 93.
} 
pronounced existentialism an important vogue that captured "an historical mood" of pessimism that might be "aesthetically appropriate to our age." 15 In the same journal, foreign affairs editor J. Alvarez Del Vayo, from a left-wing perspective, dismissed existentialism as a retrograde individualist philosophy and the latest European vogue, replacing the vogues of Nietzsche and Bergson. ${ }^{16}$ As late as 1949 in The Vital Center, Arthur Schlesinger positively recommended "the vogue of existentialism" for its willingness "to grapple with the implications" of "anxiety," "frustration," and "isolation" associated with freedom. ${ }^{17}$

The notion that existentialism was a vogue or fad and Sartre's treatment as a celebrity conditioned the reception of existentialism at both the popular and academic levels. In France, Sartre, the Sorbonne superstar, had transformed the fields of philosophy and literature through a torrent of essays, lectures, novels, and plays and solidified his scholarly influence through the founding of the journal Les Temps Modernes. But in the less intellectually rigid United States, rather than being consigned to the slow process of dissemination through academic philosophy or literature journals, existentialism exploded on the national consciousness. In mass circulation magazines, the doctrine and figures of existentialism were considered fashionable, which meant that they must be discussed, rendered assimilable for a popular audience. But this also implied that the French existentialists and the influence of their ideas were ephemeral. ${ }^{18}$

In more intellectual journals, existentialism was confronted in much the same manner, albeit in fuller fashion. Thus in Partisan Review, various New York intellectuals, led by William Barrett and Delmore Schwartz, attempted to gauge the importance of existentialism for an American audience. As early as 1946, Barrett had evaluated Sartre's work in "The Talent and Career of Jean-Paul Sartre." In addition, the Partisan Review had published two stories drawn from the early novel Nausea and the influential piece "Portrait of an Anti-Semite," which was to be published by Schocken in full book form in 1948. Sartre worked to build his reputation with American intellectuals with a host of essays between 1946 and 1948. He also published "Forgers of Myth: The Young Playwrights of France" in Theatre Arts and "American Novelists in French Eyes" in Atlantic. Beauvoir's "Eye for Eye" was

\footnotetext{
${ }^{15}$ Greenberg, "Jean Dubuffet and French Existentialism," Nation, 13 July 1946, reprinted in The Collected Essays and Criticism of Clement Greenberg: Arrogant Purpose, 1945-1949, ed. John O'Brien (Chicago, 1986), 91-92.

${ }^{16}$ J. Alvarez Del Vayo, "Politics and the Intellectual," Nation, 28 September 1946, 346.

${ }^{17}$ Arthur M. Schlesinger Jr., The Vital Center: The Politics of Freedom (New York, 1988), 52.

${ }^{18}$ Boschetti, The Intellectual Enterprise, 57.
} 
translated in 1947 for politics, a radical journal edited by Dwight Macdonald, and the general availability of existentialist works markedly increased as the publishing industry translated shorter works for an American audience. In addition to Schocken's publication of Anti-Semite and Jew, the Philosophical Library made available Sartre's Existentialism (1947) and What is Literature? (1949). In addition, they also brought out a slim volume by Jean Wahl, A Short History of Existentialism (1949), to meet the demand for existentialist works. ${ }^{19}$

Despite the growing body of existentialist literature, American intellectuals often felt distanced from existentialists and their ideas. In part, the failure of American intellectuals to engage fully with existentialism in the late 1940s and early 1950 s testified to their desire to establish the hegemony of American modernism. As Serge Guilbaut has argued, American intellectuals and artists sought to establish New York as the intellectual and artistic capital of the world. In addition, intellectuals increasingly viewed popular culture as devoid of value, indeed, as part and parcel of the massification of the mind that was particularly conducive to ideological constructs such as communism and fascism and contrary to serious discourse. ${ }^{20}$

In turn, as Andrew Ross has posited, popular culture was inundated by resentment and suspicion toward the figure of the intellectual. As the Cold War deepened, the vision of the intellectual as dangerous and beholden to an alien, communist ideology, as a figure to be contained, became common in America. The conservative, rabidly anticommunist writer Louis Bromfield captured the current of antagonism in American culture against the intellectual in 1952 with his definition of an "egghead":

A person of spurious intellectual pretensions, often a professor or the protégé of a professor. Fundamentally superficial. Over-emotional and feminine in reactions to any problem. Supercilious and surfeited with conceit and contempt for the experience of more sound and able men.... A self-conscious prig, so given to examining all sides of a question that he becomes thoroughly addled while remaining always in the same spot. An anemic bleeding heart. ${ }^{21}$

\footnotetext{
${ }^{19}$ Sartre, "Forgers of Myth," Theatre Arts, June 1946, 324-34; "American Novelists in French Eyes," Atlantic, August 1946, 114-18; Beauvoir, "Eye for Eye," politics 4 (July-August 1947): $134-40$.

${ }^{20}$ Paul R. Gorman, Left Intellectuals and Popular Culture in Twentieth-Century America (Chapel Hill, 1996), 137-85; Serge Guilbaut, How New York Stole the Idea of Modern Art: Abstract Expressionism, Freedom, and the Cold War, trans. Arthur Goldhammer (Chicago, 1983).

${ }^{21}$ Ross, No Respect: Intellectuals \& Popular Culture (New York, 1989); Louis Bromfield, "The Triumph of the Egghead," Freeman, 1 December 1952, 158.
} 
Yet, a contrasting image of the intellectual, that of hearty, bourgeois citizen, was introduced in 1954 when Time placed sociologist and intellectual David Riesman on its cover. After briefly discussing Riesman's seminal ideas in The Lonely Crowd (1950) and his recently published Individualism Reconsidered (1954), in an informational box entitled "An Autonomous Man," Time demonstrated Riesman's staggering breadth of knowledge, which he managed to communicate through the nonspecialized "lingo" of his prose. In addition to being a family man, Riesman was athletic, well dressed, and appreciative of good food and wine. But he was more than a highbrow, since he favored fantasy films over intellectual "message movies." 22 Gone was the image of the intellectual as bohemian or as subversive; in its stead was the intellectual as a middle-class everyman. Well into the 1950 s, the popular cultural representation of the intellectual was contested terrain, balanced between negative representations of the intellectual as dangerous alien and other, more positive depictions of the intellectual as a respectable and productive member of society. ${ }^{23}$

The image of the existentialist as developed in the popular press contrasted with these images. First, Riesman's depiction in a sense represented the "growing up" or coming of age of the existentialist into a responsible citizen. After all, both Riesman and the existentialists were concerned mightily with the individual, with issues of autonomy in an age of increasing conformity. But their differing lifestyles, the cafe habitué versus the family man, divided them fully, and Riesman was generally considered superior both as a serious and relevant thinker and as a role model. Second, while the existentialists in the popular press were rarely considered political threats associated with communism, they were viewed snidely as socially odd. In this sense, they were perceived as potential, however weak, challengers to American social and cultural hegemony. They were objects of fashion, to be ogled and wondered at rather than taken too seriously.

In one of the first notices of Sartre and French existentialism, Time reported that Sartre's "temple, [is] the respectfully bohemian Cafe de Flore on the Left Bank. There he spends most of his writing and preaching day." ${ }^{4}$ More detail on the cafe and bohemian lifestyle marked a long essay in Life, which carried the rather daunting subtitle: "Amid Left-Bank revels, postwar France enthrones a bleak philosophy of pessimism derived by a French atheist from a Danish mystic." Sartre rose early and spent much of his time at the cafe, where he was to be found "writing in long-

22“An Autonomous Man," Time, 27 September 1954, 24.

${ }^{23}$ See George Cotkin, "The Tragic Predicament': Post-war American Intellectuals, Acceptance, and Mass Culture," in Intellectuals in Politics: From the Dreyfus Affair to Salman Rushdie, ed. Jeremy Jennings and Anthony Kemp-Welch (New York and London, 1997), 248-70.

24"Existentialism," Time, 28 January 1946, 28-29. 
hand, holding business conferences, receiving visitors and newspapermen and seeing friends." ${ }^{25}$ The emphasis on the oddity of a philosopher and prodigious writer working in a public cafe became one of the distinguishing marks of the existentialist philosopher. So too did early accounts of Sartre and Beauvoir remark about their accommodations. In the New York Times Magazine, Sartre was depicted in his cafe habitat, drink in hand, "appearing undisturbed by the buzzing about him." Sartre's life was "that of the unattached intellectual of the Left Bank, a life divided between the hotel room where he sleeps and the cafe table where he reads, writes, drinks, receives his friends." 26

But these habits, detailed in so many of the essays, were also patronizingly viewed as remnants, soon to be cast off as success spoiled the existentialist leaders. From bohemianism to respectability seemed to be the subtext of popular magazine discussions of the existentialist lifestyle. Thus the essay in the New York Times Magazine found that Sartre and Beauvoir's early bohemianism, when "[n]o compromise with convention was permitted," had become a thing of the past. Now, "Sartre is a pontiff, de Beauvoir a well-groomed literary lady who has abandoned hand-knitted hose for the sheerest of nylons." Moreover,

Now that they are respectable and well heeled, the old defiance and desperation are going out of them. Steam heat and modern plumbing have lured them away from the cold and not very clean [hotel] Louisiana. The age of scandal is over, they are making their peace with society, and who knows but that Sartre may end up in the French academy and Simone de Beauvoir in the College de France. ${ }^{27}$

All commentators on French existentialism before 1950 found it a pessimistic philosophy. Janet Flanner in the New Yorker described it in 1945 as based upon "a disgust for humanity." ${ }^{28}$ Since Sartre's magnum opus, Being and Nothingness, would not be translated into English until 1956, popular descriptions of existentialism generally relied on Nausea and Huis-clos, as well as on Camus's The Myth of Sisyphus and The Stranger. The premise of Huis-clos, which had a rather short run on Broadway in 1946, revolved around a set of damned souls forced to endure "the

\footnotetext{
${ }^{25}$ Bernard Frizell, "Existentialism," Life, 17 June 1946, 60.

${ }^{26}$ John L. Brown, "Chief Prophet of the Existentialists: Sartre of the Left Bank has a philosophy that provokes both sermons and fistfights," New York Times Magazine, 2 February 1947, 20.

${ }^{27}$ Ibid., 21, 52.

${ }^{28}$ Flanner, "Paris Journal," 49.
} 
crushing weight of eternity." According to one reviewer, it proved the Sartrean point that hell is other people. ${ }^{29}$ Time magazine remarked weakly that out of such despair came the responsibility to act, to make something of one's life. Even Camus, who eventually tried to distance himself from existentialism, was perceived to be working out of an existentialist notion of despair and pessimism. In a review of The Stranger, negatively titled "Man in a Vacuum," Time noted that "existential pessimism underlines every cold, gross, irrational detail of the story."30

Yet, hope for the existentialist vision of man as trapped in absurdity undergoing change seemed in the offing. After all, many observed, the leading existentialists hardly seemed pessimistic in their own personal lives. While admitting an "absurdiste" aspect to Camus's writing, the philosopher himself was described as "unduly cheerful," just as Sartre was perceived as a merry philosopher during his visit to New York City in the early spring of 1946 . When confronted with his apparent personal optimism in contrast to his philosophical pessimism, Camus was quoted: "Just because you have pessimistic thoughts, you don't have to act pessimistic." ${ }^{\prime 11}$ In similar fashion, Life noted that Sartre was a hard worker but also described his ability to enjoy himself. Sartre and Beauvoir "fortify their pessimism with succulent dinners topped by excellent vintages and rounded out by age-ripened liquors." After this hearty dinner, the existentialists were known to head for the nightclubs where they would dance into the wee hours of the morning. ${ }^{32}$ Thus, because of this juxtaposition of personal happiness and philosophical pessimism, the latter was often seen as a pose.

Moreover, when not viewed as a pose, existential pessimism was considered specific to the postwar European experience. The contemporary postwar era was a bleak period in French history, remarked a writer for Life, naturally they had developed a bleak philosophy. "France was literally crushed in 1940 and the subsequent occupation. Many, particularly the intellectuals, feel lost, abandoned and hopeless." 33 In the strange existentialist juxtaposition of "degradation and dignity," noted Time, "Sartre's philosophy undoubtedly responds to the desperate need among modern pagans in Europe and elsewhere to find some rational justification for individual life and effort." ${ }^{34}$ Implicit in this analysis was the perception that once

29"No Exit," Theatre Arts, January 1947, 16.

30"Existentialism," Time, 29; "Man in a Vacuum," 92-93; see also "The Eternal Rock Pusher," Newsweek, 15 April 1946, 97-99.

\footnotetext{
31 “Absurdiste," New Yorker, 20 April 1946, 22-23.

${ }^{32}$ Frizell, "Existentialism," 60, 62.

${ }^{33}$ Ibid.

34"Existentialism," Time, 29.
} 
scarcity and suffering had passed, existentialism would no longer be relevant. Indeed, Sartre and Beauvior's personal journey into luxury and success seemed an analog for the recovery of Europe. Uncompromised bohemianism and a culture of scarcity connected to a philosophy of despair were being left behind as Sartre and Beauvoir embraced a respectable and well heeled lifestyle.

The attention that existentialism received in the popular press, then, was considerable, as befitted a vogue or a fad. The major players were perceived as celebrities, as intellectual bohemian outsiders, and their philosophy fundamentally irrelevant to an American culture that seemed to be moving in the direction of what sociologists would soon be calling "corporate man." Missed, too, in the pessimistic turn of existentialism were the philosophical imperatives that existentialism offered in the wake of the atomic bomb, the Holocaust, and World War II, and the coming dangers of the Cold War and nuclear age. Existentialism was often presented as little more than a fashionable import that Americans ogled and smirked at but kept their distance from.

By 1946 the popular and highbrow press had begun to satirize existentialism. In order to work well, satire must have an object that is sufficiently familiar for people to get the joke. After the media blitz of 1946-47, existentialism came to be perceived in the popular mind as a French philosophy of bleak despair, marked with abstract concepts and big words (existentialism, ontology, metaphysics). This was captured in a satirical piece in Time in 1946, where it was "reported" that the existentialists were now being referred to in Paris as the "excrementalists," and that such once "true-blue bohemians" as Sartre were now "bourgeois" because they were "making money." With the reputation of the existentialists "tarnished," one Pascal, a waiter at the Cafe de Flore, lamented the drop in patronage now that existentialism was being challenged by new "ism's" or fads such as "Lettrism" and "Sensoralism." "We must combat them if we wish things to remain as they were in the good old days" of two years ago. Such was the cash value of existentialism from the perspective of a Parisian waiter. ${ }^{35}$

In a Sunday New York Times Magazine article, "Thingness of Things," Paul F. Jennings wrote of the latest fashion in French thought, "Resistentialism," currently making a splash in the cafe scene. Founded by one Pierre-Marie Ventre, resistentialism was "a philosophy of tragic grandeur" that reversed the long-term epistemological quest for humans to fix the nature of things. In contrast to traditional philosophy, counterphenomenological resistentialism was "the philosophy of what Things think about us." ${ }^{36}$ So well conditioned had Americans become to the presumed outrageousness of French philosophical fashion that at least one person

\footnotetext{
35"Pursuit of Wisdom," Time, 2 December 1946, 31.

${ }^{36}$ Jennings, "Thingness of Things," New York Times Magazine, 13 June 1948, 19-20.
} 
reportedly found resistentialism to be "a wonderful theory. She hoped that Ventre's play Puits Clos would hit Broadway soon, not realizing that the whole thing was a take-off on Jean-Paul Sartre's Existentialism and on his play Huis Clos (No Exit)."37

Similarly, in the more highbrow Partisan Review, Delmore Schwartz satirically worried that existentialism was "being taken more and more for granted, like cynicism, optimism, surrealism, alcoholism, and practically all the other well-known topics of conversation." He proposed a "revival of interest in the meaning of existentialism," concluding that existentialism could "be reduced to the following formulation: Existentialism means that no one else can take a bath for you." As Schwartz explained,

This example is suggested by Heidegger, who points out that no one else can die for you. You must die your own death. But the same is true of taking a bath. And I prefer the bath as an example to death because, as Heidegger further observes, no one likes to think very much about death, except indigent undertakers perhaps. Death is for most a distant event, however unpleasant and inevitable.

A bath, however, is a daily affair, at least in America. Thus it is something that you have to think about somewhat everyday, and while you are thinking about it, and while, perforce, you are taking a bath, you might just as well be thinking about what existentialism means. Otherwise you will probably just be thinking about yourself, which is narcissism; or about other human beings, which is likely to be malicious, unless you are feeling good; or worst of all, you may not be thinking at all, which is senseless and a waste of time. ${ }^{38}$

Yet existentialism during the postwar years was not simply reduced to caricature and satire. The popular and middlebrow press had presented existentialism in terms of fashion, to be sure. But, as Rene Konig avers, fashions take on a life of their own; they extrude beyond the boundaries of the ridiculous and insinuate themselves into all the nooks and crannies of culture; no intellectual paradigm is hermetically sealed. Existentialism, while being dismissed as a fad, was also being popularized and disseminated, and while its popular reception in the short term undermined its acceptance by America's leading intellectuals, in time some intellectuals did attempt serious expositions of existentialist ideas that took into account the universal challenge that existentialism issued. But it took a good 10 years to achieve this shift. Thus, in such books such as Irrational Man (1958) by William Barrett and An

\footnotetext{
${ }^{37}$ Norman Sak, "Letter to the Editor," New York Times Magazine, 27 June 1948, 4.

${ }^{38}$ Delmore Schwartz, "Does Existentialism Still Exist?," Partisan Review, December 1948, 1361.
} 
Existentialist Ethics (1967) by Hazel E. Barnes, intellectuals finally moved away from the view that existentialism was species specific to the postwar European situation and instead sought to situate existentialism within the history of philosophy and to view it as a rigorous and important challenge to the realities of Americans. ${ }^{39}$

Their work set the stage for another generation of thinkers in the 1960 s to find in existentialist doctrines a congenial and compelling worldview. Roxanne DunbarOrtiz, growing up dirt poor in Oklahoma but later a founder of the radical feminist collective Cell 16 in Cambridge, Massachusetts, recalled that when she read Sartre's Being and Nothingness, "The words exploded in my head. I read that huge turgid tome, retaining words that defined my feelings-ennui, alienation, nausea." And Beauvoir's The Mandarins made her wish "to be in Paris with people who would understand and teach me."40

The attraction of French intellectual fashions continued well into the 1960s and 1970s. As Alice Kaplan recalled in her memoir French Lessons, "in 1966 I first heard the word 'existentialism.' .. . It was the longest word I had ever heard. French was this, too, always - even in beginning French classes you heard there was a France beyond the everyday, a France of hard talk and intellect, where God was dead and you were on your own, totally responsible." 41

The dissemination of existentialism continued to be caught up in the image, in the fashion of the intellectual and the allure of Paris, as testified to by both Kaplan and Dunbar-Ortiz, women from strikingly different backgrounds. In the 1960s, the connection between the image of the intellectual as celebrity and the content of existentialism was reiterated, and a generation of New Left student radicals found in the existentialists not only role models for the life of the committed intellectual but ideas that exemplified a proper analysis of the world. The image of the celebrity, the allure of Parisian fashion, and the power of the ideas intertwined, helping to define the thought of an era. ${ }^{42}$

\footnotetext{
${ }^{39}$ Rene Konig, A la Mode: On the Social Psychology of Fashion, trans. F. Bradley (New York, 1973), 47; William Barrett, Irrational Man: A Study in Existential Philosophy (Garden City, N.Y., 1958); Hazel E. Barnes, An Existentialist Ethics (Chicago, 1967).

${ }^{40}$ Roxanne Dunbar-Ortiz, Red Dirt: Growing Up Okie (London, 1997), 206; see also Alice Echols, Daring to Be Bad: Radical Feminism in America, 1967-1975 (Minneapolis, 1989), 158-66.

${ }^{41}$ Alice Kaplan, French Lessons: A Memoir (Chicago, 1993), 138.

${ }^{42}$ See Doug Rossinow, "The Break-through to New Life': Christianity and the Emergence of the New Left in Austin, Texas, 1956-1964," American Quarterly 46 (September 1994): 309-40.
} 